\title{
Nasoata Mangrove Island, the PABITRA Coastal Study Site for Viti Levu, Fiji Islands ${ }^{1}$
}

\author{
R. R. Thaman, ${ }^{2}$ Gunnar Keppel, ${ }^{3}$ Dick Watling, ${ }^{4}$ Batiri Thaman, ${ }^{5}$ Timoci Gaunavinaka, ${ }^{6}$ \\ Alifereti Naikatini, ${ }^{7}$ Baravi Thaman, ${ }^{8}$ Nemani Bolaqace, ${ }^{9}$ Etika Sekinoco, ${ }^{9}$ and Manasa Masere 9
}

\begin{abstract}
Nasoata Island is a predominantly mangrove island located near the outflow and delta of the Rewa River, Fiji's largest and longest river. The river originates on the eastern slopes of Mt. Tomaniivi in the Central Highlands of Viti Levu. The island has been selected as an integral coastal site for Fiji's PABITRA Gateway Transect. Information is provided on: (1) the reasons it was selected as a PABITRA site; (2) geographical, geological, climatic, and edaphic setting; (3) the vegetation; and (4) brief notes on the fauna, with particular focus on the avifauna. Because of its rich flora and fauna, Nasoata Island is an excellent "prototype" coastal and mangrove site for enhancing our understanding of the complexities of island biodiversity, both within Fiji and in relation to other small offshore islands within the broader PABITRA network.
\end{abstract}

Nasoata is a small, predominantly mangrove island located in the Rewa River Delta, near the outflow of the Nasoata River, one of the main subsidiary channels of the Rewa River, Fiji's largest and longest river, which empties into the Pacific Ocean in southeastern Viti Levu (Figure 1). Because of its relatively pristine condition, its relatively rich flora, avifauna, and marine biodiversity, particularly its migratory birds, seabirds, and waterfowl, and its rich mangrove-associated crustacean fauna, the island has been selected

\footnotetext{
${ }^{1}$ Manuscript accepted 27 April 2004.

2 Professor of Pacific Islands biogeography, University of the South Pacific, Suva, Fiji Islands.

${ }^{3}$ Assistant lecturer in biology, University of the South Pacific, Suva, Fiji Islands.

${ }^{4}$ Environmental consultant and ornithologist, Environmental Consultants Fiji, Ltd., Suva, Fiji Islands.

${ }^{5}$ Scientific officer, Institute of Applied Science, University of the South Pacific, Suva, Fiji Islands.

${ }^{6}$ Coordinator, Fiji National Ramsar and Wetlands Working Group, Suva, Fiji Islands.

${ }^{7}$ Technical assistant, South Pacific Regional Herbarium, University of the South Pacific, Suva, Fiji Islands.

${ }^{8}$ Tutor in geography, University of the South Pacific, Suva, Fiji Islands.

${ }^{9}$ Community leader, Nakorovou Village, Rewa Province, Viti Levu, Fiji Islands.
}

Pacific Science (2005), vol. 59, no. 2:193-204

(C) 2005 by University of Hawai'i Press

All rights reserved as a prototype coastal mangrove site in the PABITRA mountain-to-sea landscape transect originating at Mt. Tomaniivi and the Central Highlands of Viti Levu and extending along the Rewa River system to the coral reefs and nearshore marine ecosystems of southeastern Viti Levu.

The information presented here is based on five reconnaissance visits to Nasoata between April 2001 and August 2002, during which time preliminary assessments were made of the flora and fauna of the island and the surrounding nearshore environment. Based on these preliminary assessments the island was first selected as one of Fiji's priority mangrove wetland sites under the Ramsar Wetland Convention and subsequently for designation as the coastal and mangrove site within the proposed Fiji PABITRA Gateway Transect. The main reasons for its selection include (1) it is an uninhabited offshore island, which makes it an excellent site for the study of processes within a discrete smallisland ecosystem surrounded by more diverse ecosystems of main-island Viti Levu; (2) it is a relatively undisturbed and extensive mangrove ecosystem with a diversity of associated flora and fauna; (3) limited areas of other representative coastal and nearshore marine ecosystems exist, which support beach and littoral forest, disturbed coastal forest, a coconut plantation, intertidal sea-grass beds, and 


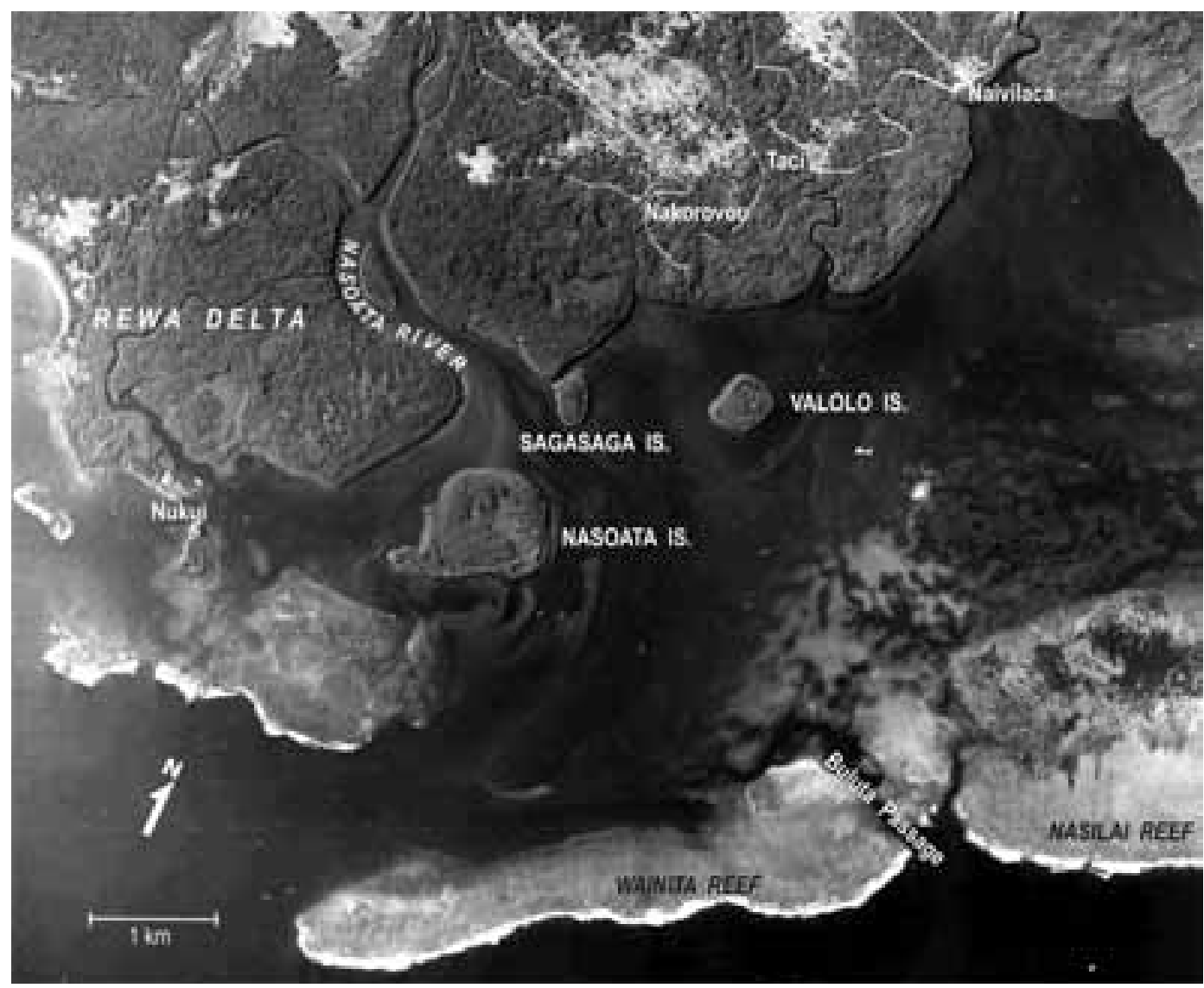

Figure 1. Annotated aerial photograph of a portion of southeastern Viti Levu centered on Nasoata Island and the lower reaches of the Nasoata River showing the main mangrove islands of Nasoata, Valolo, and Sagasaga; portions of the Rewa River Delta; fringing reefs; mudflats and associated intertidal sea-grass beds; offshore barrier reefs; reef passes; and the locations of Nakorovou Village (the custodians of Nasoata) and other Fijian villages that use the area as an important fishing ground and the islands as sources of food and other products.

mudflats; (4) its pivotal location on the windward side of Viti Levu at the mouth of the Rewa River and just off the main delta, about $1 \mathrm{~km}$ inside the main barrier reef, makes it a prime target for potential colonization by terrestrial and aquatic organisms from both the sea and the mainland; (5) the rich shorebird and seabird avifauna; (6) the rich mangrove invertebrate and vertebrate fauna of considerable economic and cultural importance; (7) the designation of the island as a reserve and a scientific study site has been strongly endorsed by the local Fijian community respon- sible for the stewardship of the island and by the Fiji Government.

GEOGRAPHY, CLIMATE, SOILS, AND TENURE

CHANGES

The area of Nasoata is about 76 ha $(0.76$ $\mathrm{km}^{2}$ ). Its maximum elevation above mean sea level is about $1.2 \mathrm{~m}$ in the higher southcentral portion of the island. It is located at about $18^{\circ} 8^{\prime} \mathrm{S}$ latitude and $178^{\circ} 36^{\prime} \mathrm{E}$ longitude. The main mouth of the Rewa River is located about $3 \mathrm{~km}$ to the west. There are 
coral reefs, including Nasilai Reef, located a further $1 \mathrm{~km}$ to the south and extending to the southeast of the island. Sagasaga and $\mathrm{Va}-$ lolo are two smaller mangrove islands located about $1 \mathrm{~km}$ to the east of the island.

Nasoata lies just off the windward southeastern portion of Viti Levu and has a wet, tropical oceanic climate. The area receives about 3,000 $\mathrm{mm}$ mean annual rainfall, with some rainfall being experienced on an average of about 250 days per year. The average annual mean temperature is $25^{\circ} \mathrm{C}\left(77^{\circ} \mathrm{F}\right)$ with an average monthly range of about $6^{\circ} \mathrm{C}$. The temperature seldom rises above $32^{\circ}$ or falls below $16^{\circ} \mathrm{C}$ (Smith 1979). The southeast tradewinds, which affect the southern coast of the island, are relatively consistent during the cooler, drier season between April and October. They shift more to the northeast later in the year. During the warm, wet season between mid-November and mid-April the entire Fiji group experiences gale-force winds. Destructive tropical cyclones, storm waves, and associated heavy rainfall are common during that period. This leads to flooding and accelerated runoff in the Rewa River system and accelerated erosion on the southeastern windward side of the island. This increased river flow brings with it increased sediment loads that affect not only the central low-lying portions of Nasoata, but also the surrounding sea-grass beds and nearby coral reefs. The increased river flow with its high sediment load also substantially reduces the biogenic proportion of beach sand on the more upraised southern portions of the island. The high river flows and storm waves also bring flotsam and propagules of many inland plants to the island. The presence of some of the noncoastal plant and animal species found on the island, including some reptiles (e.g., geckos and skinks) and countless insects, is probably due to these storm-related events. During one visit to the island in $\mathrm{Au}-$ gust 2001, just after heavy flooding in the Rewa Delta, a juvenile Pacific boa, gata (Candoia bibroni), was found in a tree just behind the beach on the southeastern corner of the island. High seas, reinforced by the predominant tradewinds, have also led to extensive deposits of pumice (soata in Fijian) through- out the low-lying areas of the southeastern portion of the island. This is the origin of the island's name, Nasoata (literally "the pumice" or place of the pumice).

The island was formerly a freehold property run as a copra plantation, first as the Hedstrom Estate, and subsequently by a Mr. B. Garnett and most recently by Ram Singh from the 1950s until the late 1970s when the title to the island was transferred from freehold to native land under the high chief of Rewa, Ro Lady Lala Mara, the Rokotui Dreketi. At the time the people of nearby Nakorovou Village were designated as the owners, custodians, and main users. Although the island was a source of construction materials for traditional Fijian houses (bure) in the past, the island is now used almost exclusively as a fishing ground (iqoliqoli) or "breadbasket" (ikanakana) and for the production of copra from the existing coconut palms on and around the old copra estate in the southeast of the island. The island was used during World War II by New Zealand and American troops as a training ground for jungle combat and, more recently, during the 1970s and early 1980s by the O Kei Viti group of $\mathrm{Na}$ korovou as a tourist destination, where Fijian cultural displays and meals were provided as a source of income to the village. It remains a favorite picnic site for schools in the area.

\section{FLORA}

The flora of Nasoata is composed of some 123 species of vascular plants from 54 families. Of these species, 15 are ferns or fern allies and the balance consists of 108 angiosperms, of which 32 are monocotyledons and 76 dicotyledons (Table 1) (see Appendix for a listing of the flora). Four of the monocotyledon species are sea grasses, from two exclusively aquatic families. All of the ferns are assumed to be indigenous, whereas 36 of 106 angiosperms are probably introduced species, half of which (18) are assumed to be either accidental introductions by humans or recent natural arrivals to the island carried from mainland Viti Levu by the river, waves, birds, or fruit bats (see Appendix). There are no gymnosperms on the island. 
TABLE 1

Summary of the Composition of the Flora of Nasoata Island Based on Studies Conducted from 2001 through 2003 (a Detailed Listing of Species Is Included in the Appendix)

\begin{tabular}{lcccr}
\hline \hline Flora & Families & Indigenous & Introduced & Total \\
\hline Pteridophyta (ferns and fern allies) & 9 & 15 & - & 15 \\
Monocotyledonae (monocots) & 13 & 22 & 10 & 32 \\
Dicotyledonae (dicots) & 32 & 50 & 26 & 76 \\
Total vascular plants & 54 & 87 & 36 & 123 \\
\hline
\end{tabular}

Vegetation Types

The main vegetation types on Nasoata include Rhizophora- and Bruguiera-dominated mangrove forest, mixed tidal forest, episodic swamp forest, inland coastal forest or coconut woodland, littoral forest and strand vegetation, ruderal vegetation, and sea-grass beds. Figure 2 is a general vegetation map showing these vegetation types.

RHIZOPHORA FOREST (VEI TIRI OR VEI KAKA). The eastern and northern coastal zone of the island is dominated by Rhizophora stylosa (tiri solo) and Rbizophora mangle (tiri or tiri wai), with the former generally occupying the outer fringes and the latter the inner, more protected areas of this mangrove forest system. There are also areas of dense thickets dominated almost exclusively by Rhizophora spp. along the outer edges of the central Bruguiera-dominated Bolavou Swamp in the south-central part of the island. These impenetrable thickets are known in Fijian as veikakaka. A sterile hybrid, Rhizophora stylosa $\times$ mangle, known in Fijian as selala, which is occasional in other parts of Fiji, is also found, but uncommon, on the island. At least one selala, approximately $15 \mathrm{~m}$ in height, was seen, which is similar in height to the uppercanopy Rhizophora spp. in the area.

BRUGUIERA GYMNORRHIZA SWAMP FOREST. Most of the poorly drained central swampy portion of the island is covered by an extensive mangrove swamp forest. This vegetation type is dominated almost entirely by large Bruguiera gymnorrhiza as the uppercanopy species, with the occasional presence of individuals of Xylocarpus granatum in more well-drained sites. The largest trees in the up- per canopy are up to $16 \mathrm{~m}$ high. Scattered throughout this community is the mangrove or swamp fern (Acrosticum aureum). Also common in this plant community is a range of epiphytic ferns, including Davallia fijiensis, Davallia solida, Pyrrosia lanceolata, and Nephrolepis sp. Less common ferns include the climbing fern, Stencblaena palustris, and the epiphytic ferns Vittaria elongata, Vaginularia angustifolia, and Drynaria rigidula. The latter was seen as a single, large fern growing on a Bruguiera tree in the center of Bolavou Swamp. The other ferns are mainly found growing on Bruguiera and Xylocarpus trees, often on older, often broken branches. The epiphytic orchid Grammatophyllum elegans was also seen on a number of dead trunks and branches of B. gymnorrbiza. Lumnitzera littorea was reportedly a common component of this forest in the past but was logged out because of its value as one of the most durable and desirable woods for houseposts for Fijian houses.

MIXED TIDAL FOREST. There are also small areas of mixed tidal forest, usually on the southern edges of the Bruguiera gymnorrbiza forests or in slightly raised, more well-drained sites on the southern and northeastern sides of the island. These mixed forests are mostly dominated by either $X y$ locarpus granatum or Excoecaria agallocha, although scattered Rbizophora spp. and Bruguiera gymnorrhiza are also found. Heritiera littoralis and Intsia bijuga are occasional trees in this mixed tidal forest. The introduced invasive species known as pond apple, Annona glabra, is also present. Occasional throughout this community are the large sedges Scirpodendron ghaeri and Mariscus javanicus. Other 


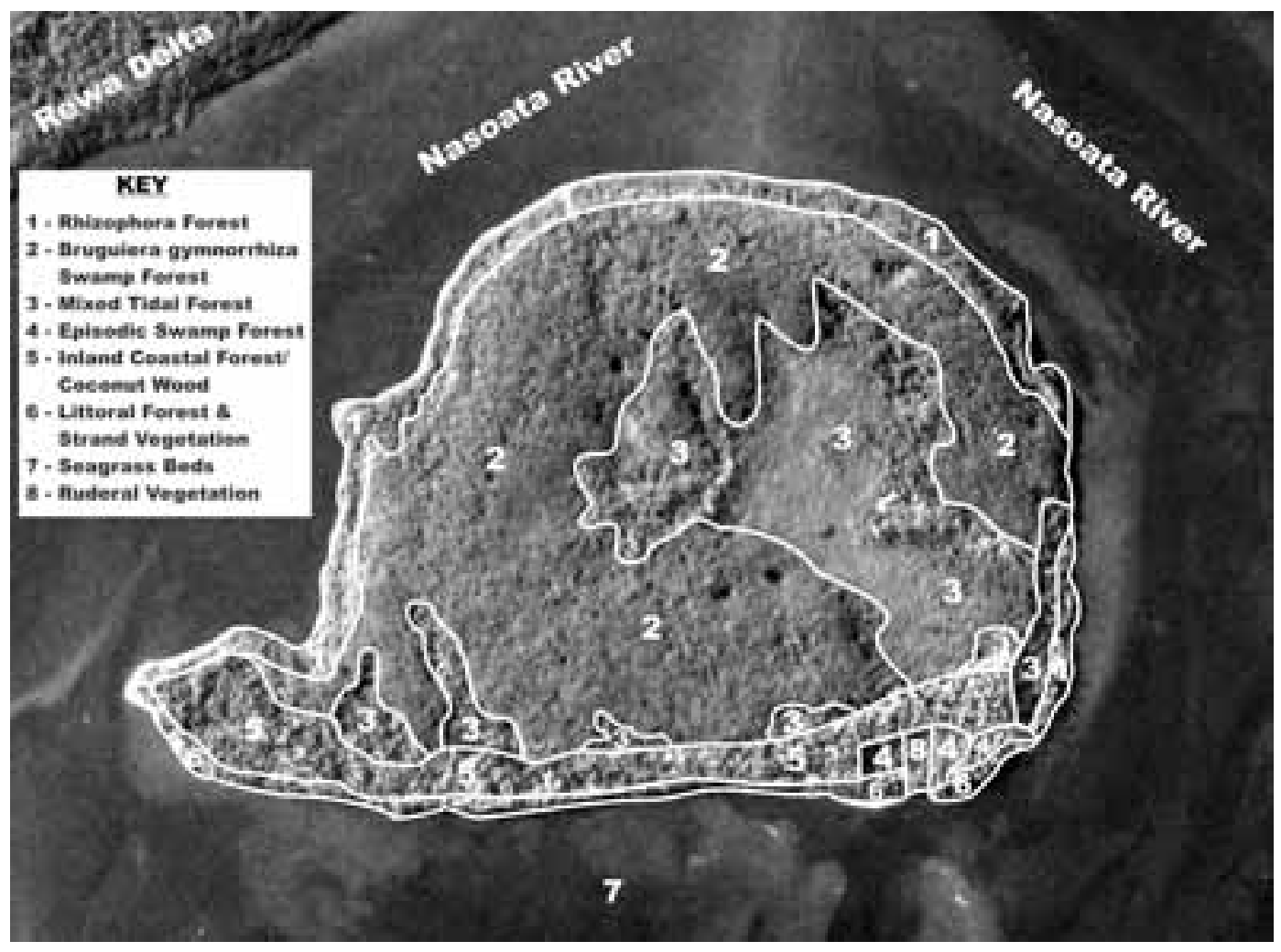

Figure 2. Generalized vegetation map of Nasoata Island, Rewa Delta, Viti Levu, Fiji Islands (prepared by Baravi Thaman from a 1994 aerial photograph).

common species include the climbing vines Derris trifoliata, Dalbergia canadatensis, and Entada phasioloides; the mangrove fern, Acrostichum aureum; and the epiphytic ferns $D a-$ vallia fijiensis, Davallia solida, and Pyrrosia lanceolata. Uncommon to occasional are the climbing swamp fern, Stenochlaena palustris, and the epiphytic orchids Taeniophyllum fasciola and Oberonia balophila (the latter two were seen on a Morinda citrifolia tree, the same species that hosts orchids in the Veisari mangrove forest on southeastern Viti Levu). In one area in the southern portion of the island, in a back-beach basin, the introduced invasive species pond apple (Annona glabra) has established itself in limited areas in almost monospecific stands, probably in areas formerly covered with Rhizophora.
EPISODIC SWAMP FOREST. There are limited areas of relatively open forest that are episodically subjected to swampy conditions. These are found in a number of sites that are frequently waterlogged or submerged with brackish water, due to a rising water table, during exceptionally high spring tides associated with heavy rains. This intermediate vegetation type is restricted to a narrow belt, which is found mainly on the southeastern part of the island slightly inland from the beach forest and on the southeastern windward border of the central Bolavou Swamp. The substrate is intermediate between the muddy mangroves and sandy beaches but also includes a large proportion of highly acidic pumice, in various stages of breakdown. Common trees of this community include the mangrove associates Excoecaria 
agallocha, Heritiera littoralis, and Barringtonia asiatica on the outer edges, with Inocarpus fagifer, Cocos nucifera, and Hibiscus tiliaceus dominating the more well-drained sites that are less subject to saline overflow from the tidal areas. Other scattered shrubs or small trees include Morinda citrifolia and Barringtonia racemosa. The latter is found occasionally in low-lying spots that are periodically swampy. Also common in these sites are the climbers Smythea lanceolata, Derris trifoliata, and Entada phasioloides. In more expansive areas of this type, there are aggregations of Xylocarpus granatum and a few individuals of Intsia bijuga (others probably have been logged out in the past, because the wood is useful for construction purposes). Climbers and epiphytes are absent or similar to those in the mixed swamp forest.

INLAND COASTAL FOREST OR COCONUT WOODLAND. There are substantial areas of inland coconut-dominated coastal forest or woodland on better-drained sites on the southeastern and southern parts of the island, just inland from the raised beach ridge. These areas are rarely, if ever, inundated. Much of the original vegetation in these areas was undoubtedly cleared during the establishment of copra plantations during the middle of the last century, but there are remnants of the original native vegetation. Recent natural recolonization by pioneer species has also occurred as coconut plantations were abandoned or not maintained. Native tree species are found scattered throughout this community. Some may have been planted as multipurpose trees when permanent residents were on the island. These trees include Cerbera manghas, Pongamia pinnata, Xylocarpus granatum, Barringtonia asiatica, Inocarpus fagifer, Tarenna sambucina, Dysoxylum ricbii, Ficus vitiensis, Erythrina variegata var. orientalis, and the introduced Annona glabra. Shrubby species include Morinda citrifolia, Ficus barclayana, Geniostoma sp., and the introduced Lantana camara. Occasional naturally occurring climbing vines or lianas include Derris trifoliata, Smythea lanceolata, Entada phaseoloides, the adventive Passiflora laurifolia, the terrestrial fern Phymatosorus grossus, and the mainly epiphytic ferns Davallia fijiensis, Davallia solida, Pyrrosia lanceolata, Vittaria elongata, Vaginularia angustifolia, and Nephrolepis spp., the latter of which are both epiphytic and terrestrial. The grass Centotheca lappacea; the sedge Scleria polycarpa; the adventive herbs Polygala paniculata, Clidemia birta, Vernonia cinerea, and Spermacoce sp.; and the epiphytic orchids Appendicula reflexa, Taeniophyllum fasicola, and Oberonia balophila are also present. There are rare remnants of cultivation: the air yam (Dioscorea bulbifera) and derris root (Derris malaccensis), which is a source of rotenone used by Fijians to poison fish.

LITTORAL FOREST AND STRAND VEGETATION. There are relatively extensive areas of littoral forest and strand vegetation along the south coast of the island. These fall into two relatively distinct types. The first occurs on the more windward southeastern and southcentral coast of the island, which has been strongly and continually eroded. The second occurs on the southwestern coast of the island, which is eroded to a much lesser extent. The beaches of Nasoata differ from other comparable ones in having terrestrial sand brought in with the river outflow mixed with sand from coral reef and oceanic sources. These mixed sands are, therefore, likely to be richer in nutrients than the sands of most coastal littoral beaches. The accelerated coastal erosion reportedly was most pronounced during Tropical Cyclone Bebe in 1972. Many coconut palms and other large coastal trees were uprooted and serious erosion of topsoil along the inner margins of the coastal vegetation occurred at that time. This initial major erosion has been reinforced by more recent storms and associated high seas.

In the outpost or frontal zone of the littoral beach forest on the southern side of the island are the trees Cocos nucifera, Hibiscus tiliaceus, Excoecaria agallocha, Hernandia nymphaeifolia, Thespesia populnea, Calophyllum inophyllum, Cerbera manghas, Pandanus tectorius, Terminalia catappa, Premna serratifolia, and a few young individuals of Rhizophora samoensis; the shrub Clerodendrum inerme; the grasses Paspalum vaginatum and Lepturus repens; the sedge Cyperus stoloniferus; and the spreading 
or climbing vines, Canavalia rosea, Ipomoea pescaprae, Ipomoea macrantha, and Vigna marina. The southwestern coast vegetation has a similar composition but also includes some isolated individuals or relicts of the original coastal littoral forest. These include Tournefortia argentea and Xylocarpus moluccensis and the shrub Scaevola taccada. The only remaining individual of red-flowered mangrove, Lumnitzera littorea, is also found in the outer coastal zone along the beach on the southwestern coast of the island. This tree species was reportedly abundant on the coastal margins of the mangroves in the past, but was harvested for houseposts. In a number of places the aliens trailing daisy (Wedelia trilobata) and Para grass (Brachiaria mutica) are successfully outcompeting the indigenous herbaceous species (e.g., Ipomoea pes-caprae, Canavalia rosea, and Vigna marina). These introduced plants constitute a threat to this vegetation type.

RUderal vegetation. There are limited areas of ruderal vegetation found mainly in and around the former Hedstrom settlement, in well-drained areas formerly utilized as copra plantations, and in a limited number of open sites in more well-drained parts of the island. The former site is dominated by Cocos nucifera in the tree layer with undergrowth dominated by the grasses Ischaemum indicum and Brachiaria mutica. Occasional weedy species include Mimosa pudica, Vernonia cinerea, Polygala paniculata, and Clidemia hirta. In less-open areas, the undergrowth may consist of Annona glabra, Lantana camara, and other introduced plants, as well as some members of the inland coastal forest vegetation. Along the southern front of the former Hedstrom Estate, the introduced groundcover Wedelia trilobata has become established. It is now found in about five sites along the southern coast and constitutes a threat to the indigenous coastal littoral vegetation and the plants that border the mangrove swamp. Its eradication from the island is suggested as an immediate priority.

SEA-GRASS BEDS. There are relatively extensive areas of sea-grass beds located on the intertidal sand-mud flats and subtidal areas along the oceanside southern coast of the island. The dominant species include Halophila ovalis, Halodule pinifolia, and Halodule uninervis. The dominant species in the deeper, sandier subtidal areas off the intertidal flats is Syringodium isoetifolium, which is also a dominant component of the flotsam and drift deposits along the beaches and in back-beach basins.

\section{FAUNA}

The fauna of the island and surrounding mud flats is very rich given the small size of the island. Particularly important is the rich avifauna, a number of other vertebrates, arthropods, and other terrestrial invertebrates. The culturally important crustacean fauna, shellfish, and many other intertidal marine invertebrates are present. In-depth studies have not yet been conducted on the marine fauna and flora. The subtidal and riverine areas around the island contain a rich finfish fauna. Studies focusing on the diverse arthropod fauna are lacking.

\section{Avifauna}

Preliminary estimates indicate that there are at the very least 14 species of land, freshwater, shore-, and seabirds resident on or visiting the island (Table 2). Further studies conducted during different times of the year and at night will undoubtedly add to this list.

Of particular interest is the abundance of the Pacific black duck, which is commonly seen in flocks feeding or resting on mudflats, including about 60 in three flocks counted from one spot during a lunch break in April 2001. This was the largest number ever seen at one time in Fiji by resident bird expert Dick Watling, who has studied birds in Fiji for over 35 yrs. Also common to occasional are the collared kingfisher, the wattled honeyeater, and the Vanikoro broadbill. A rather surprising, perhaps disturbing, observation was the presence of six individuals of the introduced jungle mynah in the mangroves, which has been shown to outcompete indigenous birds, especially in disturbed habitats (Watling 1982). 
TABLE 2

Land, freshwater, shore-, and seabirds reported present on Nasoata Island and on surrounding mudflats, based on a survey by D. Watling in April 2001

\begin{tabular}{|c|c|c|}
\hline Fijian Name & Common Name & Scientific Name \\
\hline \multicolumn{3}{|l|}{ Land and freshwater birds } \\
\hline Belō & Reef heron & Egretta sacra \\
\hline visakō & Mangrove heron & Butorides striatus \\
\hline gā ni Viti & Pacific black duck & Anas superciliosa \\
\hline$s \bar{o} s \bar{o}$ & Collared kingfisher & Todiramphus chloris \\
\hline kikau & Wattled honeyeater & Foulebaio carunculata \\
\hline matayalo, solesole waqa, tina ni uto & Vanikoro broadbill & Myiagra vanikorensis \\
\hline maina $\bar{a}$ & Jungle mynah & Acridotheres fuscus \\
\hline \multicolumn{3}{|l|}{ Sea- and shorebirds } \\
\hline kasaga & Lesser frigatebird & Fregata ariel \\
\hline$i c \bar{o}$ & Crested tern & Sterna bergii \\
\hline turi $\bar{\imath}$ & Whimbrel & Numenius phaeopus \\
\hline dilio & Pacific golden plover & Pluvialis fulva \\
\hline batibalavu, teitei kai dawa & Bar-tailed godwit & Limosa lapponica \\
\hline dilio seasea & Turnstone & Arenaria interpres \\
\hline juli & Wandering tattler & Heteroscelus incanus \\
\hline
\end{tabular}

In terms of Fiji's shore- and seabird fauna, the extensive mudflats adjoining the island are of major interest with respect to Nasoata's possible nomination as a conservation area under the Ramsar Wetlands Convention. Over 300 waders were observed on these mudflats in April 2001. Most were wandering tattlers, which are the last waders to leave on their northern migration (they leave in late April or early May). Fiji's other common waders, the golden plovers, bar-tailed godwits, and turnstones, already would have commenced their northern migration, which accounts for their low numbers at that time. Also relatively abundant were whimbrels, seen off the southern beach. If these waders occur around Nasoata in the same proportion as they do at Suva Point, where the numbers are regularly monitored, then peak numbers in February to March at Nasoata are estimated to be approximately $900-1,000$, a very impressive number by Fijian standards. The other bird seen in substantial numbers was the crested tern, of which some 50 were seen resting on flats adjacent to the island. Two of these mudflats are quite elevated and concentrate the waders as the tide rises, allowing them to rest and feed when much of the surrounding flat is submerged.

\section{Other Vertebrates}

Reptiles seen on the island include blue-tailed and copper skinks (Emoia cyanura and Emoia impar), which were common; the moth skink (Lipinia noctua); the oceanic gecko (Gebyra oceanica); and the mourning gecko (Lepidodactylus lugubris). Neither the snake-eyed skink (Cryptoblepharus eximius) or the green tree skink (Emoia concolor) were observed but may well occur. As mentioned above, a juvenile Pacific boa, one of Fiji's two native land snakes, was also seen in a coastal tree after a major flood that swept past the island in $\mathrm{Au}-$ gust 2001. It has not been seen since.

The only indigenous terrestrial mammals are nonresident fruit bats (Pteropus tonganus), which fly from the mainland to feed on the island. Of concern is the presence of the introduced mongoose (Herpestes auropunctatus), which is common on the island and is a major threat to ground-nesting birds and crabs. Rats (Rattus spp.) may also occur on the island. 


\section{Terrestrial Invertebrates}

Although formal studies have not been conducted, preliminary studies conducted by a PABITRA team in November 2002 indicate that there is a relatively diverse terrestrial invertebrate fauna. This includes a range of centipedes and millipedes, spiders, butterflies, moths, stick insects, grasshoppers, beetles, flies, bees, wasps, ants, and other insects, most of which have important ecological roles on the island. The wide range of specimens collected in 2002 still awaits identification.

\section{Marine Fauna}

The most immediately obvious components of the marine fauna are the economically and culturally important crustaceans that abound on the island. Most notable is the mangrove or mud lobster or manā (Thalassoma anomala), which is caught using an ingenious traditional snaring system. It is in season between December and April and sold at local urban markets as an important source of income. There are two species of mangrove crabs, the redclawed mangrove crab or kuka damu (Sesarma erytbrodactyla) and the black mangrove crab, kuka vulu or uka loa (Metapograpsus messor). There is also the larger mud crab, qari (Scylla serrata). These three crab species are common in the mangrove habitats. In addition, the land crab, lairo or tuba (Cardisoma carniflex), is found in more well-drained sites. All of these species are hunted in season and sold at local markets as an important source of cash income. Commonly caught prawns or shrimp include ura (Penaeus spp.), kadikadi (Macrobrachium equidens), and moci (Palaemon concinnus). These species are also sold. The rock crab, taqara (Grapsus albolineatus); the box crab, cugavotu (Calappa hepatica); and a number of species of fiddler crabs, toto (Uca spp.), and hermit crabs, uga (Ceonobita spp.) occur along the coastline or on the mudflats. The latter is considered a preferred bait species for line fishing. Penaeid prawns or shrimps (Penaeus spp.) are common on the reef flat and are seasonally caught for local consumption and sale.
Commonly collected mangrove-associated shellfish include mangrove oysters, dio (Crassostrea mordax); nerite snails, sisici or telei (Nerita spp.); periwinkles, sisi ni veidogo (Littorina scabra); sponge-finger oysters, drivi (Vulsella vulsella); mangrove mussels, kuku (Modiolus agripetus); and saddle tree oysters, civaciva (Isognomon ephippium). These are not commonly sold and are used mainly for subsistence. Other edible shellfish found on the mudflats include ark shells, kaikoso (Anadara antiquata) and kaibakoko (Codakia spp.); venus clams, qeqe or qaqa (Gafarium tumidum); and moon snails, drevula (Polynices spp.). Also common on the mudflats are lamp shells, ivoce (Lingula unguis); peanut worms, ibo (Siphonosoma australe); and the sandfish or dairo, a species of bêche-de-mer (Metriatyla scabra).

Commonly caught finfish include qitawa (Terapon jarbua); ki (Upeneus vittatus); kaikai (Gazza minuta and Leiognatbus equulus); kake (Lutjanus fulviflamma); matu (Gerres spp.); damu (Lutjanus bohor); kurukoto (Eleotris melanosoma); kawakawa (Epinephelus spp.); nuqa (Siganus spp.); kabatia (Letbrinus harak); kanace (Crenimugil crenilabi, Valamugil sabeli); molisā (Liza melinoptera or small mullet); and freshwater eels, duna (Anguilla marmorata) (Thaman 1998). Some of these fish are sold, although most are consumed in the local communities. The mudskipper, tidrai (Periophthalmus argentimaculatus), is also common but not eaten.

\section{CONCLUSIONS}

The observations made during seven trips to Nasoata Island in 2001 and 2002 have confirmed Nasoata as a prime mangrove study site, which offers a wide range of opportunities to conduct controlled studies of the mangrove ecosystem and other associated terrestrial, riverine, and marine ecosystems surrounding the island. The island constitutes a good example of a "classical" Rewa Delta mangrove ecosystem with fringing tiri (Rbizophora spp.) and extensive mature stands of dogo intertidal swamp forest (Bruguiera gymnorrbiza), known as Bolavou Swamp. Scattered throughout the island, mostly on the 
southern margins of Bolavou Swamp, are slightly raised areas with impressive stands of dabi (Xylocarpus granatum) and Heritiera littoralis. This mangrove swamp forest is as impressive as any seen anywhere in Fiji. With the exception of reported widespread removal of Lumnitzera littorea (now a critically threatened species on the island), the current use of the island seems to be on the whole nondestructive. Overall the mangroves look almost untouched, whereas many similar areas on mainland Viti Levu have had some logging. However, Nasoata was never included in the Forestry Department's plan for the exploitation of timber and firewood in the Rewa mangroves.

There are a number of introduced plant species that have been shown to have been highly invasive in other areas of Fiji. These include the trailing daisy (Wedelia trilobata), which was seen in five locations on the southern coast of the island. This plant has invaded mangroves, river courses, and coastlines on mainland Fiji and other areas in the Pacific Islands and could become one of the most invasive weeds in the Pacific Islands. It could lead to serious ecological disturbance, particularly on small offshore islands and in mangrove ecosystems. The pond apple ( $A n$ nona glabra) is naturalized in limited areas of back-beach swamps on the southeastern portion of the island, where it now forms almost monospecific stands of large trees. Also of concern is a member of the pepper family, the hooked pepper bush, Piper aduncum. It is currently uncommon but has become a serious weedy large shrub in coastal areas elsewhere in Fiji. Para grass (Brachiaria mutica) is dominant on a couple of beach terraces on the south-central and southwestern portions of the island and is outcompeting the herbaceous outpost vegetation along beaches. Also of concern are the introduced mongoose and the jungle mynah bird, which could lead to the collapse of populations of some native vertebrate and invertebrate animals. Concerted attempts should be made to eradicate or control these pest species so that they do not become ecologically dominant or destructive on the island.
In short, Nasoata Island is an accessible, complex mangrove ecosystem with associated terrestrial, freshwater, and marine ecosystems. It is ideally located at the extreme southeastern end of the PABITRA Gateway Transect, which extends from cloud forest to mangrove and coral reef ecosystems. The PABITRA Gateway Transect includes Fiji's largest river system, the Rewa River and its upstream catchments and lower delta, as an integrated system. The high level of terrestrial, freshwater, and marine biodiversity, including the presence of some introduced, potentially invasive species, also adds to the value of the PABITRA landscape for the study of interacting ecosystems. The fact that the island is seen by the local user communities as their "breadbasket" (ikanakana) and is currently being used in what appears to be a sustainable manner, adds an important human dimension, so central to the PABITRA philosophy. Finally, the strong support from the local communities, who are responsible for caring for and using the island, for the designation of the area as a conservation site and scientific study area further adds to the importance of Nasoata Island as an integral component of the Fiji PABITRA Gateway Transect. This also underlines its suitability for designation as a priority site for protection under the Ramsar Wetlands Convention.

\section{Literature Cited}

Smith, A. C. 1979. Flora Vitiensis nova: A new flora of Fiji (spermatophytes only). Vol. 1. Pacific Tropical Botanical Garden, Lāwa'i, Kaua'i, Hawai'i.

Thaman, B. 1998. Community utilisation and valuation of mangrove resources in Fiji: Case studies of Sawa, Daku and Nadoria Villages and Kinoya and Tamavua-i-wai urban settlements, Viti Levu, Fiji. M.S. thesis, James Cook University of North Queensland, Townsville, Australia.

Watling, D. 1982. Birds of Fiji, Tonga and Samoa. Millwood Press, Wellington, New Zealand. 


\section{Appendix}

Field Checklist of the Flora of Nasoata Island, Rewa Delta, Rewa Province, Viti Levu, Fiji Islands

\begin{tabular}{|c|c|}
\hline Pteridophyta (Ferns and Fern Allies) & Appendicula reflexa $\mathrm{Bl}$. \\
\hline Aspleniaceae (Spleenwort Fern family) & Grammatophyllum elegans Reichenb. f. \\
\hline Asplenium nidus L., bird's-nest fern & Oberonia beliophila Reichenb. f. \\
\hline Blechnaceae (Water Fern family) & Taeniophyllum fasciola (Forst. f.) Seem. \\
\hline $\begin{array}{l}\text { Stenochlaena palustris (Burm.) Beddome, swamp or } \\
\text { mangrove fern }\end{array}$ & $\begin{array}{l}\text { Pandanaceae (Pandanus family) } \\
\text { Pandanus tectorius Warb., pandanus, screw pine }\end{array}$ \\
\hline Davalliaceae (Hare's-Foot Fern family) & Poaceae or Graminae (Grass family) \\
\hline Davallia fejeensis Hooker, Fiji hare's-foot fern & *Arundo donax L., reed \\
\hline Davallia solida (Forst. f.) Swartz, hare's-foot fern & *Brachiaria mutica (Forsk.) Stapf, para grass, \\
\hline Nephrolepidaceae (Sword Fern family) & Mauritius grass \\
\hline Nephrolepis biserrata (Sw.) Schott, fishtail fern & Centotheca lappacea (L.) Desv. \\
\hline $\begin{array}{l}\text { Nephrolepis hirsutula (Forst.) Presl., sword fern, } \\
\text { fishtail fern }\end{array}$ & $\begin{array}{l}\text { *Ischaemum indicum (Houtt.) Merr., Batiki blue } \\
\text { grass }\end{array}$ \\
\hline Polypodiaceae (Polypody Fern family) & Lepturus repens (G. Forst.) R. Brown, beach \\
\hline Drynaria rigidula (Sw.) Bedd., basket fern & bunch grass \\
\hline $\begin{array}{l}\text { Phymatosorus grossus (Langsd. \& Fisch.) Brownlie, } \\
\text { scented fern }\end{array}$ & $\begin{array}{l}\text { **Oplismenus compositus (L.) Beauv., basket grass } \\
\text { Miscantbus floridulus (Labill.) Warb., sword grass }\end{array}$ \\
\hline $\begin{array}{l}\text { Pyrrosia lanceolata (L.) Farwell, lanceolate felt fern } \\
\text { Psilotaceae (Psilotum family) }\end{array}$ & $\begin{array}{l}\text { Paspalum vaginatum } \mathrm{S}_{w .,} \text { knot grass, salt grass, } \\
\text { swamp couch grass }\end{array}$ \\
\hline $\begin{array}{l}\text { Psilotum nudum (L.) Beauv., psilotum, reed fern, } \\
\text { whisk fern }\end{array}$ & $\begin{array}{l}\text { Sporobolus cf. elongatus (Retz.) Beauv.?, wiregrass } \\
\text { Stenotaphrum micranthum (Desv.) Hubb. }\end{array}$ \\
\hline Pteridaceae (Brake Fern family) & Thuarea involuta (Forst. f.) R. Br. ex R. \& S. \\
\hline Acrosticum aureum L., swamp fern, mangrove fern & Taccaceae (Polynesian Arrowroot family) \\
\hline Pteris tripartita Sw., lacy fern, sword brake & ${ }^{*}$ Tacca leontopetaloides (L.) O. Kuntze, Polynesian \\
\hline Vittariaceae (Tape Fern family) & arrowroot \\
\hline Vaginularia angustissima (Brack.) Mett., grass fern & Zingiberaceae (Ginger family) \\
\hline Vittaria elongata Swartz, tape fern & *Zingiber zerumbet (L.) Sm., wild ginger \\
\hline Schizaeaceae & Dicotyledonae (Dicots) \\
\hline Schizaea dichotoma (L.) Sm., branched comb ferm & Anacardiaceae (Cashew or Rhus family) \\
\hline Angiospermae (Angiosperms) & ${ }^{*}$ Mangifera indica L., mango \\
\hline Monocotyledonae (Monocots) & Annonnaceae (Custard Apple Family) \\
\hline Agavaceae (Century Plant family) & **Annona glabra L., pond apple \\
\hline $\begin{array}{l}{ }^{*} \text { Cordyline fruticosa (L.) A Chev., cordyline, ti } \\
\text { (Hawai'i) }\end{array}$ & $\begin{array}{l}\text { Apiaceae (Parsley family) } \\
{ }^{*} \text { Centella asiatica }(\mathrm{L} .) \text { Urban, Asiatic pennywort }\end{array}$ \\
\hline Araceae (Arum family) & Apocynaceae (Dog-bane family) \\
\hline Epipremnum pinnatum (L.) Engl., taro vine & Cerbera manghas L., cerbera \\
\hline Arecaceae or Palmae (Palm family) & *Plumeria rubra L., frangipani, plumeria \\
\hline Cocos nucifera L., coconut palm & Asclepiadaceae (Milkweed family) \\
\hline Commelinaceae (Spiderwort family) & Hoya australis $\mathrm{R}$. Br. ex Traill, wax vine \\
\hline${ }^{* *}$ Commelina diffusa Burm. f., day flower & Asteraceae (Sunflower family) \\
\hline Cymodoceaceae (Cymodocea family) & ${ }^{* *}$ Mikania micrantha Kunth, mile-a-minute, mile- \\
\hline $\begin{array}{l}\text { Halodule uninervis (Forssk.) Aschers, sea grass } \\
\text { Halodule pinifolia (Miki) den Hartog, sea grass }\end{array}$ & $\begin{array}{l}\text { a-minute vine } \\
* \text { Vernonia cinerea }(\text { L.) Less., iron weed }\end{array}$ \\
\hline $\begin{array}{l}\text { Syringodium isoetifolium (Aschers.) Dandy, turtle } \\
\text { grass }\end{array}$ & $\begin{array}{l}{ }^{*} \text { Wedelia trilobata (L.) Hitchc., wedelia, trailing } \\
\text { daisy }\end{array}$ \\
\hline Cyperaceae (Sedge family) & Wollastonia biflora (L.) DC., beach sunflower \\
\hline${ }^{* *}$ Cyperus rotundus L., nut sedge, nut grass & Barringtoniaceae (Barringtonia family) \\
\hline Cyperus stoloniferus Retz., beach sedge & Barringtonia asiatica (L.) Kurz., fish-poison tree, \\
\hline icus (Houtt.) Merr., marsh sedge & $\begin{array}{l}\text { barringtonia } \\
\text { Barringtonia rac }\end{array}$ \\
\hline Scleria polycarpa Boeck. & Boraginaceae (Borage family) \\
\hline Dioscoreaceae (Yam family) & Cordia subcordata Lam., sea trumpet, kou (Hawai'i) \\
\hline *Dioscorea bulbifera L., bitter yam, air yam, aerial & Tournefortia argentea L. f., beach heliotrope \\
\hline & Caricaceae (Papaya family) \\
\hline Hydrocharitaceae & ${ }^{*}$ Carica papaya L., papaya, papaw \\
\hline Halophila ovalis (R. Br.) Hook f., salt-loving sea & Clusiaceae or Guttiferae (Mangosteen family) \\
\hline $\begin{array}{l}\text { grass } \\
\text { Orchidaceae (Orchid family) }\end{array}$ & $\begin{array}{l}\text { Calophyllum inophyllum L., Alexandrian laurel, } \\
\text { beach mahogany }\end{array}$ \\
\hline
\end{tabular}


Appendix (continued)

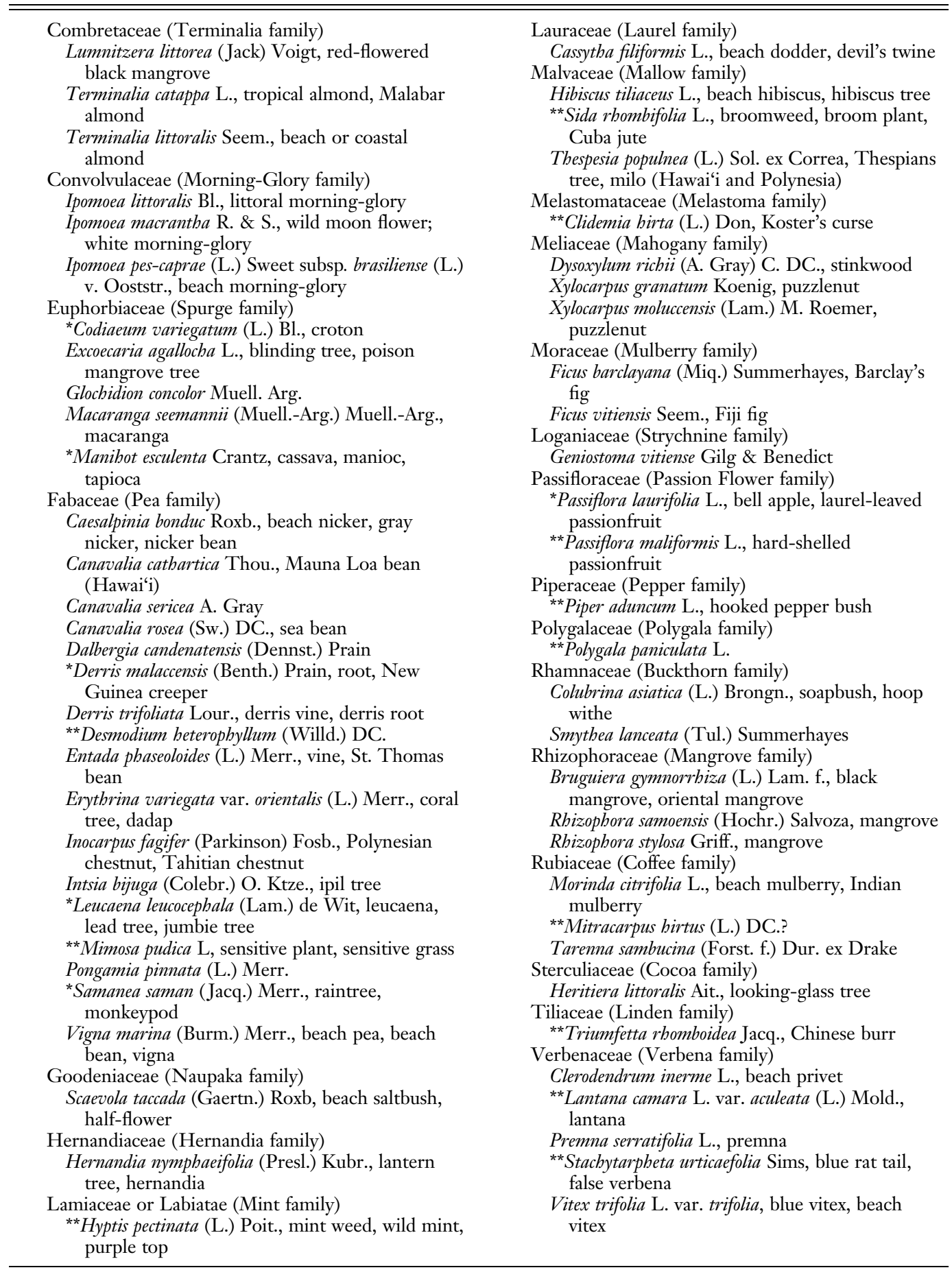

*, Species that are considered to be nonindigenous but of deliberate introduction by humans. **, Species that are assumed to be either accidental introductions or nonindigenous species that made it to the island naturally through either river or animal dispersal (e.g., bird or fruit bat). 